\title{
Knowledge, attitudes, and practices of Indonesian residents regarding COVID-19: A national cross-sectional survey
}

\author{
Yodang Yodang ${ }^{1}$, Stefanus Mendes Kiik ${ }^{2}$, Achmad Fauji ${ }^{3}$, Hamka Hamka $^{4}$, Rizky Meuthia Pratiwi ${ }^{5}$, \\ Nuridah Nuridah $^{6}$, Rahmad Yusuf $^{7}$, Yossi Fitrina ${ }^{8}$ \\ ${ }^{1,6}$ Department of Nursing, Universitas Sembilanbelas November Kolaka, Indonesia \\ ${ }^{2}$ Department of Nursing, Sekolah Tinggi Ilmu Kesehatan Maranatha Kupang, Indonesia \\ ${ }^{3}$ Department of Nursing, Sekolah Tinggi Ilmu Kesehatan Bani Saleh Bekasi, Indonesia \\ ${ }^{4}$ Fasilitas Layanan Kesehatan, NCI Center Samarinda, Indonesia \\ ${ }^{5}$ Department of Nursing, Sekolah Tinggi Ilmu Kesehatan Bina Sehat PPNI Mojokerto, Indonesia \\ ${ }^{7}$ Department of Nursing, Universitas Negeri Gorontalo, Indonesia \\ ${ }^{8}$ Department of Nursing, Sekolah Tinggi Ilmu Kesehatan YARSI Sumbar Bukittinggi, Indonesia
}

\begin{tabular}{l} 
Article Info \\
\hline Article history: \\
Received Nov 2, 2020 \\
Revised Feb 14, 2021 \\
Accepted Mar 15, 2021 \\
\hline
\end{tabular}

\section{Keywords:}

COVID-19

Female

Government

Indonesia

Pandemics

\begin{abstract}
Coronavirus disease (COVID-19) infection has been a major public healthrelated issue worldwide, including Indonesia. The COVID-19 cases still escalating until this study finished in June 2020 due to the disease positively spreading from person to person. To reduce the spreading of the disease, investigating Indonesian's knowledge, attitudes, and practice on COVID prevention and mitigation during the outbreak period was crucial. A survey cross-sectional was conducted and using social networking apps to recruit participants. All Indonesian residents who have 18 years old and over and living in Indonesia during the COVID-19 outbreak were voluntarily invited to participate in this study. There are 3464 participants involved in this study. The mean age was 27.63 years, and mostly were women, domicile in Java, held bachelor degrees, students, Muslims, and single/never married. The lowest mean practices score was found among residents who live in Maluku, Papua, and Papua Barat, senior high qualification, unemployed, indigenous religions, and single/never married. The majority of Indonesian residents have good knowledge, positive attitudes, and good practice to promote COVID-19 prevention and mitigation to reduce the pandemic spreading within the country. However, there is a lack of knowledge, attitudes, and practice among a particular group of participants.
\end{abstract}

This is an open access article under the $\underline{C C B Y-S A}$ license.

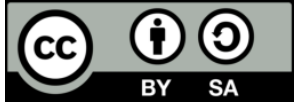

\section{Corresponding Author:}

Yodang Yodang

Department of Nursing

Universitas Sembilanbelas November Kolaka

339 Pemuda Street, Tahoa, Kolaka, Sulawesi Tenggara 93517, Indonesia

Email: yodang.usnkolaka@gmail.com

\section{INTRODUCTION}

Began in December in 2019, a respiratory disease of unknown causes was declared and clustered in Wuhan, Hubei Province, in the Republic of China [1]. Regarding the World Health Organization report, the latest and contemporary outbreak of a respiratory pathogen, namely severe acute respiratory syndrome coronavirus 2 (SARS-coV-2) responsible for coronavirus disease (COVID-19) [2], on June 1, 2020, there were 6,057,853 confirmed cases and 371,166 deaths worldwide [3]. Due to the illnesses rapidly outbreak through worldwide, the WHO declared that disease as a global pandemic [4]. The most massive outbreaks 
have linked to social gathering, delay in diagnosis, and poor infection control practices due to the lack of knowledge and attitude on COVID-19 promotion and prevention [5]. The virus of COVID-19 to spread is mainly from person to person, and through respiratory droplets produced by someone who infected person when cough and sneezes [6].

As a more massive archipelagos country on earth, Indonesia is situated between two oceans (Hindia and Pacific) and two continents (Asia and Australia). That situation brings Indonesia at a high risk from communicable and high spreadable infectious diseases, particularly virus-caused diseases such as Coronavirus infection. In Indonesia, at the early of March 2020, two people were confirmed to have COVID19, and since then, the number of cases increased significantly until June 5, 2020. There were 29.521 confirmed, 9,443 recovered, and 1,770 deaths [7]. The prevalence predicted will continues to increase since the vaccine is still ongoing research [8].

To reduce the spreading of the COVID-19, the Indonesian government ruled out some regulations, especially the province where many residents confirmed the COVID-19, such as Jakarta, West Jawa, and East Jawa. Since the mid of March, people who reside in Jakarta prohibited going out, and vice versa. Besides that, restrictions for big-scale social gatherings also applied [9].

Since the mid of June 2020, the government announced the new everyday life within the country without neglecting health protocol for residents when they leave home. However, the incidence of COVID19 confirmed increase significantly during two weeks since the new everyday life applied. Nearly a thousand patients COVID-19 confirmed each day, and these contribute to 46,845 cases on June 22, 2020 [10]. There are some factors identified which associated with diseases spreading in community these knowledge and prevention practice. Further, Ethiopian scholars point out that improving knowledge and prevention practice of the community through regular updates of COVID-19 was a crucial. Besides that, the study also reported that age and news from media were significantly related to good of knowledge on COVID-19 [11]. A scholar from Egypt discovered that inadequate knowledge and the incorrect atitudes were directly influence practices and lead to delayed diagnosis, poor infection control practice, and spread of disease within the community [12].

The COVID-19 pandemic is a mainly health disaster in this decade, and almost the countries all over the world their attention have being focused on a set of critical intervention, and promoting protocol for prevention and mitigation the pandemic spread [13].

To battle the spreading of the diseases in the community, identification of knowledge, attitudes, and practices (KAP) among Indonesian residents is essential and necessary. Some studies found that the KAP affects resident adherence to prevention and mitigation program of disease control [14]. Further, according to the SARS outbreak in 2003, the study reported that knowledge and attitudes were strongly associated with a psychological issue. As a result, prevention to spread the disease was thoroughly attempted. Despite the unprecedented national measures in fighting the outbreak, the result of these efforts is essentially dependent on public attitudes or behavior. In [15] Additionally, residents with a high level of knowledge on and positive attitudes toward COVID-19 tend to have better preventive behavior and behavioral compliance. In [16] Further, assessing residents or public knowledge is also important in identifying gaps and strengthening ongoing prevention effort. To support the Indonesian government in COVID-19 outbreak management, there was a crucial to understand residents' awareness related to the pandemic condition during the outbreak period.

To the best of our knowledge, this study is the first to assess the knowledge, attitudes, and practices of Indonesian residents towards COVID-19 in huge number of participants from across the country, from west to east (Sabang to Merauke), and from north to south (Tahuna to Rote island). Therefore, in this study, we investigate residents' awareness by measuring knowledge, attitudes, and practices, and sociodemographics related data towards COVID-19 in Indonesia among Indonesian residents. The finding of this study is expected to offer fruitful information to policymakers, and also inform public health officials on further public health interventions, awareness, and policy improvements pertaining to the COVID-19 outbreak.

\section{RESEARCH METHOD}

A national cross-sectional survey was conducted from May 8 to June 30; during this time of period, social gathering restriction was applied within the country. Conducting national community-based investigation during the period was not feasible due to stay at home regulation still spread all over the country and choosing online methods to collect data of the study. There is some social-networking app used to share the questionnaire to potential participants, namely WhatsApp, Facebook, Telegram, Twitter, and Email. Residents who were living and staying in Indonesia were aged 18 years old or more, were used information communication technology devices (mobile phones, computers neither desktop or laptop), and 
agreed to participate in the study by clicking the survey link and completed the whole questionnaire. The questionnaire was distributed by resident's thorough private channels and group channels in the socialnetworking apps. Indonesian residents who were living and staying in overseas during the study conducted were restricted from evolving.

This study approved by the Institutional Research Board of Universitas Sembilanbelas November Kolaka and "Health Research Ethics Committee of Universitas' Aisyiyah Yogyakarta," with number decree 1628/KEP-UNISA/V/2020, issued the ethical approval. The ethics committee approved the study protocol and procedure before the questionnaire delivered to potential participants as a formal online survey. The participant needs to answer the yes-no question to confirm that the willingness to participate voluntarily in the study. Confirmation to agree to be a participant was followed by the fulfillment and completion of the self-reported questionnaire. All collected data were anonymous.

The questionnaire was adopted from Zhong et al. in 2020 and developed and modified from other questionnaires; these relevant to the Indonesian context and pilot tested on a small number of Indonesian residents. The questionnaires consisted of two parts socio-demographics and KAP (knowledge, attitudes, and practices).

Socio-demographics variables included age (in year), gender, and region of current residence, education, employment status, religion, and marital status. The region of current residence was categorized into six groups, "Sumatera," "Jawa," "Bali and Nusa Tenggara," "Kalimantan," "Sulawesi," and "Maluku and Papua/Papua Barat." For education question was indicated the highest level of schooling attained, and was classified into seven groups, "elementary," "junior high," "senior high," "diploma," "bachelor," "masters," "doctorate," and "other/never study."

Employment status was assessed, by asking if they were currently worked or not. The employment status was classified into six groups, "students," "government officer/army/police," "private company officer," "self-employed," "household," and "unemployed." For the religion question, we only consider seven religions as used by the Indonesian government; "Islam," "Catholic," "Lutheran/Christianity," "Hinduism," "Buddhism," "Confucianism," and "indigenous religions." Marital status was classified into three groups, "married," "never married/single," and "others," encompassing separated, divorced, and widowed.

A COVID-19 KAP (knowledge, attitude, and practices) questionnaire was adopted from Zhong et al. [14], and modified by using some references include national guidelines, which issued by the Ministry of Health of the Republic of Indonesia [10], and the national team force for COVID-19 control and mitigation. In the knowledge-related questionnaire had 13 questions, which consist of clinical features/ clinical signs and symptoms, transmission route, and prevention control and mitigation. These questions were answered on a true/false basis with an additional "I don't know" option. Attitudes towards COVID-19 were measured through 10 items. These questions were answered on an agree/disagree basis. Furthermore, the practices to prevent and mitigate the COVID-19 were measured by 10 questions. These questions were responded to on an "Always/very often/sometimes/rarely/never" basis.

The correct answers of KAP domains were counted in frequencies. Comparison between KAP scores and demographic characteristics were analyzed with independent- samples $t$-test, one-way analysis of variance (ANOVA), and Mann-Whitney and Kruskal-Wallis tests as an optional test when data/respondents undistributed normally. To identify factors associated with KAPs, analyzing the demographic variables as independent variables and KAP score as the outcome variable using multivariable linear regression was applied. The statistical significance level was set at $\mathrm{p}<0.05$ (two-sided), and their $95 \%$ confidence intervals (CIs) were used to quantify the associations between variables and KAP.

\section{RESULT AND DISCUSSION}

In this section, it is explained the results of research and at the same time is given the comprehensive discussion. Results can be presented in figures, graphs, tables and others that make the reader understand easily [2], [5]. The discussion can be made in several sub-chapters.

The data were analyzed using IBM SPSS (statistical package for social sciences) version 23 (SPSS Inc., Chicago, IL, USA). Descriptive statistics describe the characteristics of the sample, which including frequency, percentage, mean, and standard deviation (SD). Distributions of socio-demographic characteristics among participants were analyzed using the Chi-square test. Bivariate analysis was done to examine the relationship between the socio-demographic and self-reported knowledge, attitudes, and practices among participants in COVID-19 prevention and mitigation during the outbreak.

To the best of our knowledge, this is the first study in Indonesia measuring and examining the KAP to battle COVID-19 prevent and mitigate the spreading during the outbreak period among Indonesian residents using a large number of participants from all Indonesian regions. 


\subsection{Sociodemographics indices}

This study included 3,464 eligible respondents who filled out the questionnaire completely and submitted it. The questionnaires were created using a Google form and distributed using social networking apps such as WhatsApp, Facebook, Telegram, Twitter, and email.

The mean age of the participants is 27.63 year-old ( $\mathrm{SD} \pm 8.67$ ), $70.1 \%$ are women. $45.9 \%$ live in Jawa, $51.6 \%$ hold bachelor degree, and $38.7 \%$ students, $74.7 \%$ Muslims, and $61.7 \%$ are single/never married.

\subsection{Knowledge about towards COVID-19}

The correct answer rates of the 13 questions on the COVID-19 prevention and mitigation knowledge questionnaire are $0.5-99.1 \%$ as shown in Table 1 . The mean score of COVID-19 prevention and mitigation knowledge differs among socio-demographic characteristics. The knowledge score significantly varies across genders, regions of residents, educational level, occupational status, religion, and marital status. The lowest mean score within each characteristic were male (9.65, SD: 1.39), reside in Kalimantan (9.42, SD: 1.41), elementary school graduates (8.5, SD: 0.70), unemployed (9.54, SD: 1.43), Confucianism (9.33, SD: 1.15), and single/never married (9.66, SD: 1.34$)$ as shown in Table 2.

Table 1. The correct answer rates of questionnaires of knowledge towards COVID-19

\begin{tabular}{|c|c|c|c|c|c|c|}
\hline & Knowledge questions & $\begin{array}{l}\text { Correct } \\
\mathrm{n}(\%)\end{array}$ & $\begin{array}{l}\text { False } \\
\mathrm{n}(\%)\end{array}$ & $\begin{array}{l}\text { I Don't } \\
\text { Know } \\
\text { n }(\%)\end{array}$ & $95 \% \mathrm{CI}$ & $\begin{array}{c}\mathrm{p}- \\
\text { value }\end{array}$ \\
\hline 1. & $\begin{array}{l}\text { The main clinical symptoms of COVID-19 are fever, fatigue, dry cough, } \\
\text { and myalgia. }\end{array}$ & $\begin{array}{c}3098 \\
(89.4)\end{array}$ & $\begin{array}{l}300 \\
(8.7)\end{array}$ & $66(1.9)$ & $\begin{array}{c}3.64- \\
5.81\end{array}$ & 0.000 \\
\hline 2. & $\begin{array}{l}\text { Unlike the common cold, stuffy nose, runny nose, and sneezing are less } \\
\text { common in persons infected with the COVID-19 virus. }\end{array}$ & $\begin{array}{c}1610 \\
(46.5)\end{array}$ & $\begin{array}{c}1537 \\
(44.4)\end{array}$ & $317(9.2)$ & $\begin{array}{l}3.56- \\
4.82\end{array}$ & 0.000 \\
\hline 3. & $\begin{array}{l}\text { There currently is no effective cure for COVID-19, but early } \\
\text { symptomatic and supportive treatment can help most patients recover } \\
\text { from the infection. }\end{array}$ & $\begin{array}{l}3135 \\
(90.5)\end{array}$ & $88(2.5)$ & $241(7.0)$ & $\begin{array}{l}5.06- \\
8.57\end{array}$ & 0.000 \\
\hline 4. & $\begin{array}{l}\text { Not all persons with COVID-19 will develop to severe cases. Only those } \\
\text { who are elderly, have chronic illnesses, and are obese are more likely to } \\
\text { be severe cases. }\end{array}$ & $\begin{array}{l}2652 \\
(76.6)\end{array}$ & $\begin{array}{l}588 \\
(17)\end{array}$ & $224(6.5)$ & $\begin{array}{l}4.06- \\
5.68\end{array}$ & 0.000 \\
\hline 5. & $\begin{array}{l}\text { Eating or contacting wild animals would result in the infection by the } \\
\text { COVID-19 virus.sep: }\end{array}$ & $\begin{array}{c}1592 \\
(46.0)\end{array}$ & $\begin{array}{l}1872 \\
(54)\end{array}$ & - & $\begin{array}{l}3.26- \\
4.41\end{array}$ & 0.000 \\
\hline 6. & $\begin{array}{l}\text { Persons with COVID-19 cannot infect the virus to others when a fever is } \\
\text { not present. }\end{array}$ & $\begin{array}{c}2963 \\
(85.5)\end{array}$ & $\begin{array}{l}185 \\
(5.3)\end{array}$ & $316(9.1)$ & $\begin{array}{l}4.20- \\
6.35\end{array}$ & 0.000 \\
\hline 7. & $\begin{array}{l}\text { The COVID-19 virus spreads via respiratory droplets of infected } \\
\text { individuals. }\end{array}$ & $\begin{array}{l}3233 \\
(93.3)\end{array}$ & $\begin{array}{l}150 \\
(4.3)\end{array}$ & $81(2.3)$ & $\begin{array}{c}6.04- \\
11.84\end{array}$ & 0.000 \\
\hline 8. & $\begin{array}{l}\text { Ordinary residents can wear general medical masks to prevent the } \\
\text { infection by the COVID-19 virus. }\end{array}$ & $\begin{array}{l}2377 \\
(68.6)\end{array}$ & $\begin{array}{c}980 \\
(28.3)\end{array}$ & $107(3.1)$ & $\begin{array}{c}3.91- \\
5.30\end{array}$ & 0.000 \\
\hline 9. & $\begin{array}{l}\text { It is not necessary for children and young adults to take measures to } \\
\text { prevent the infection by the COVID-19 virus. }\end{array}$ & $\begin{array}{l}3355 \\
(96.9)\end{array}$ & $73(2.1)$ & $36(1.0)$ & $\begin{array}{l}4.32- \\
10.95\end{array}$ & 0.000 \\
\hline 10. & $\begin{array}{l}\text { To prevent the infection by COVID-19, individuals should avoid going } \\
\text { to crowded places such as train stations and avoid taking public } \\
\text { transportations. }\end{array}$ & $\begin{array}{l}3408 \\
(98.4)\end{array}$ & $44(1.3)$ & $12(0.3)$ & $\begin{array}{l}3.44- \\
12.43\end{array}$ & 0.000 \\
\hline 11. & $\begin{array}{l}\text { Isolation and treatment of people who are infected with the COVID-19 } \\
\text { virus are effective ways to reduce the spread of the virus. }\end{array}$ & $\begin{array}{l}3432 \\
(99.1)\end{array}$ & $10(0.3)$ & $22(0.6)$ & $\begin{array}{l}4.33- \\
35.36\end{array}$ & 0.000 \\
\hline 12. & $\begin{array}{l}\text { People who have contact with someone infected with the COVID-19 } \\
\text { virus should be immediately isolated in a proper place. In general, the } \\
\text { observation period is } 14 \text { days. }\end{array}$ & $17(0.5)$ & $\begin{array}{l}3426 \\
(98.9)\end{array}$ & $21(0.6)$ & $\begin{array}{l}0.31- \\
2.17\end{array}$ & 0.695 \\
\hline 13. & Some of persons with COVID19 have asymptomatic & $\begin{array}{c}2990 \\
(86.3)\end{array}$ & $\begin{array}{c}351 \\
(10.1)\end{array}$ & $123(3.6)$ & $\begin{array}{c}3.47- \\
5.24\end{array}$ & 0.000 \\
\hline
\end{tabular}

Table 2. Displays the socio-demographic characteristics of the participants

\begin{tabular}{|c|c|c|c|c|c|}
\hline \multicolumn{2}{|c|}{ Characteristics } & $\begin{array}{c}\text { Number of } \\
\text { participant }(\%)\end{array}$ & $\begin{array}{c}\text { Knowledge score } \\
(\text { mean } \pm \text { SD })\end{array}$ & $\begin{array}{c}\text { Attitudes score } \\
(\text { mean } \pm \mathrm{SD})\end{array}$ & $\begin{array}{c}\text { Practices score } \\
(\text { mean } \pm \text { SD })\end{array}$ \\
\hline \multirow{2}{*}{ Age } & Mean $27.63(18-75)$ & 3464 & CI (27.35-27.93) & & \\
\hline & $\mathrm{SD}(8.67)$ & & & & \\
\hline \multirow{4}{*}{ Gender } & Male & $1036(29.9)$ & $9.65 \pm 1.39$ & $8.89 \pm 0.97$ & $37.27 \pm 6.45$ \\
\hline & Female & $2428(70.1)$ & $9.82 \pm 1.26$ & $8.97 \pm 0.83$ & $38.57 \pm 5.51$ \\
\hline & Sumatera & $182(5.3)$ & $10.4 \pm 1.14$ & $8.90 \pm 0.86$ & $38.36 \pm 6.15$ \\
\hline & Jawa & $1590(45.9)$ & $9.81 \pm 1.28$ & $8.98 \pm 0.89$ & $38.13 \pm 5.65$ \\
\hline \multirow{5}{*}{$\begin{array}{l}\text { Regions of current } \\
\text { place residence }\end{array}$} & Bali and Nusa & $525(15.2)$ & $9.71 \pm 1.30$ & $8.97 \pm 0.80$ & $38.91 \pm 6.33$ \\
\hline & Tenggara & & & & \\
\hline & Kalimantan & $278(8.0)$ & $9.42 \pm 1.41$ & $8.91 \pm 0.84$ & $37.72 \pm 5.48$ \\
\hline & Sulawesi & 793 (22.9) & $9.80 \pm 1.33$ & $8.90 \pm 0.90$ & $38.16 \pm 5.83$ \\
\hline & Maluku and Papua & $96(2.8)$ & $9.69 \pm 1.30$ & $8.86 \pm 0.92$ & $36.20 \pm 5.98$ \\
\hline
\end{tabular}




\begin{tabular}{|c|c|c|c|c|c|}
\hline \multicolumn{2}{|c|}{ Characteristics } & $\begin{array}{c}\text { Number of } \\
\text { participant }(\%)\end{array}$ & $\begin{array}{c}\text { Knowledge score } \\
(\text { mean } \pm \text { SD })\end{array}$ & $\begin{array}{c}\text { Attitudes score } \\
(\text { mean } \pm \mathrm{SD})\end{array}$ & $\begin{array}{c}\text { Practices score } \\
(\text { mean } \pm \text { SD) }\end{array}$ \\
\hline \multirow{8}{*}{ Educational } & Never study & $11(0.3)$ & $9.27 \pm 1.61$ & $8.90 \pm 0.83$ & $37.45 \pm 4.61$ \\
\hline & Elementary & $2(0.1)$ & $\mathrm{n} / \mathrm{a}$ & $8.5 \pm 0.70$ & $43.50 \pm 9.19$ \\
\hline & Junior High & $20(0.6)$ & $10.10 \pm 1.33$ & $9.05 \pm 0.39$ & $37.80 \pm 7.11$ \\
\hline & Senior High & $610(17.6)$ & $9.56 \pm 1.42$ & $8.89 \pm 0.82$ & $35.96 \pm 6.37$ \\
\hline & Diploma & $510(14.7)$ & $9.87 \pm 1.24$ & $9.01 \pm 0.77$ & $39.32 \pm 5.67$ \\
\hline & Bachelor & $1789(51.6)$ & $9.75 \pm 1.31$ & $8.91 \pm 0.88$ & $38.42 \pm 5.66$ \\
\hline & Master & 473 (13.7) & $9.96 \pm 1.16$ & $9.08 \pm 0.96$ & $38.95 \pm 5.18$ \\
\hline & Doctoral & 49 (1.4) & $10.14 \pm 1.02$ & $8.87 \pm 1.39$ & $37.81 \pm 5.49$ \\
\hline \multirow{6}{*}{ Occupational } & Student & $1339(38.7)$ & $9.64 \pm 1.33$ & $8.89 \pm 0.80$ & $36.98 \pm 6.05$ \\
\hline & $\begin{array}{l}\text { Public servants/ } \\
\text { army/police }\end{array}$ & $750(21.7)$ & $9.95 \pm 1.18$ & $9.06 \pm 0.93$ & $39.46 \pm 5.50$ \\
\hline & $\begin{array}{l}\text { Private company } \\
\text { officer }\end{array}$ & $852(24.6)$ & $9.88 \pm 1.26$ & $8.98 \pm 0.90$ & $39.25 \pm 5.31$ \\
\hline & Self-employed & $125(3.6)$ & $9.60 \pm 1.60$ & $8.96 \pm 0.88$ & $38.67 \pm 6.12$ \\
\hline & Household & $162(4.7)$ & $9.91 \pm 1.30$ & $8.95 \pm 0.86$ & $38.04 \pm 5.99$ \\
\hline & Unemployed & $236(6.8)$ & $9.54 \pm 1.43$ & $8.76 \pm 1.01$ & $36.95 \pm 5.63$ \\
\hline \multirow{7}{*}{ Religion Affiliation } & Islam & $2589(74.7)$ & $9.80 \pm 1.29$ & $8.96 \pm 0.88$ & $38.09 \pm 5.81$ \\
\hline & Catholic & $263(7.6)$ & $9.69 \pm 1.23$ & $8.79 \pm 0.93$ & $38.03 \pm 5.83$ \\
\hline & Christianity & 378 10.9) & $9.44 \pm 1.41$ & $8.91 \pm 0.82$ & $37.38 \pm 6.23$ \\
\hline & Hindu & $220(6.4)$ & $10.07 \pm 1.20$ & $9.08 \pm 0.65$ & $41.00 \pm 4.32$ \\
\hline & Buddhism & $7(0.2)$ & $9.85 \pm 1.34$ & $8.85 \pm 0.69$ & $37.14 \pm 7.51$ \\
\hline & Confucianism & $3(0.1)$ & $9.33 \pm 1.15$ & $\mathrm{n} / \mathrm{a}$ & $34.33 \pm 9.23$ \\
\hline & Indigenous Religions & $4(.01)$ & $10.00 \pm 0.81$ & $7.50 \pm 3.69$ & $30.50 \pm 6.24$ \\
\hline \multirow{3}{*}{ Marital status } & Single/Never married & $2138(61.7)$ & $9.66 \pm 1.34$ & $8.89 \pm 0.88$ & $37.50 \pm 5.89$ \\
\hline & Married & $1289(37.2)$ & $9.95 \pm 1.22$ & $9.04 \pm 0.83$ & $39.28 \pm 5.52$ \\
\hline & Divorce/widow & $37(1.1)$ & $9.72 \pm 1.34$ & $8.56 \pm 1.30$ & $39.27 \pm 7.30$ \\
\hline
\end{tabular}

In this study was participated predominantly female and well-educated population, we found the correct rate of 10 out 13 of knowledge questionnaires were ranging from $68.8-99.1 \%$-the study result indicating that the majority of the respondents are knowledgeable about disease. Similar finding, a study result that investigated by Pascawati and Satoto found that the women have higher level of knowledge about COVID19 than men [17]. Another study that conducted in Malaysia reported that mean score of knowledge on COVID19 was higher in women than men [18]. The reason that women have high score on knowledge because women would actively engage on social media networking and actively learnt knowledge of the disease from various channel of information [19]. In contrast, a study conducted in Egypt found that the mean score of knowledge among men and women was almost similar, and the statistically analyzed that there is no differences in both group of gender on knowledge domain [12]. However, the number of participants could affect the study result, where more than a half of them were men. Further reasons were identified that nearly $60 \%$ of them health care workers who work in university hospital and have intermediate and university level in educational background. The study finding do not surprise because we assumed that the majority of participants already have good knowledge about COVID19. Furthermore, a study in Bangladesh also found that men have higher level on knowledge than women [20]. When we assessed the ratio of participants in that study, surprisingly nearly $60 \%$ of them were men. From these finding we point out that the proportion of participants also has significant impact on study result [21].

However, we found that one questionnaire, "People who have contact with someone infected with the COVID-19 virus should be immediately isolated in a proper place. In general, the observation period is 14 days" was very small correct answered by participants was about $0.5 \%$. The participants may have been affected by the overwhelming of the news they received thorough on television (TV) and the Internet [22]. Another scholar investigated misinformation about COVID-19 in the Indonesia community, and the study result showed that the predominant of participants have misinformation related to COVID-19, both prevention and transmission issues [23]. It was supported by a study among surveillance officers were more than $80 \%$ of them first heard and got information COVID-19 related matters from social media apps and the television. This situation may affect the residents understanding on COVID-19 prevention, hence, they have misconception on one of the protocols [24].

During this study, the government released a regulation about large-scale social restrictions (PSBBPembatasan Sosial Berskala Besar) due to the incidence of COVID-19 continues escalated until this study finished. While two questionnaires, "unlike the common cold, stuffy nose, runny nose, and sneezing are less common in persons infected with the COVID-19 virus," and "eating or contacting wild animals would result in the infection by the COVID-19 virus," were nearly a half of respondents have the correct answers $(46.5 \%$ and $46.0 \%$, respectively). Overall, men who have a lower mean knowledge score than women (9.65, SD: 
1.26). Based on this study, the majority of women may pay more attention when filling out the questionnaire compared to men. The lowest mean knowledge score we found among resident in Kalimantan (9.42, SD: 1.41), who do not qualify/never study (9.27, SD: 1.61), who have unemployed status (9.54, SD: 1.43), who are confucianism (9.33, SD: 1.15), and are single/never married (9.66, SD: 1.34). The lack of evidence to claim that the geographical residency of participants has a significant effect on knowledge since the Kalimantan residents were recruited and involved in this the national scale of study. A survey conducted by a scholar team from some Indonesian universities found that nearly $99 \%$ of participants have good knowledge on COVID-19 prevention, especially on physical distancing benefits, however, the participant from Kalimantan only represented by $8.6 \%$ of the total participants, It means that this result do not offer the best evidence since the data analysis of region-based participants was unanalyzed [25].

\subsection{Attitudes towards COVID-19}

The majority of the participants show the positive attitudes to battle and against the COVID-19 pandemic. The agree answer of the 10 questions on the outbreak management questionnaire are 33.3-99.4\% as shown in Table 3. Most of the participants (94.1\%) agree that the pandemic will eventually be successfully controlled, and $81.7 \%$ agreed that the government could win the battle against the COVID19 virus. Participants who agree with essential reporting a suspected case to health authorities are $99.4 \%$, while $97.4 \%$ of participants strongly support the government to close the schools and workplaces during the epidemics. Also, $97.4 \%$ of participants are afraid to go to common places to avoid infection, even though $96.3 \%$ of participants agree that corona infection is preventable. However, two-third of participants disagree that corona patients can be treated at home. The participants strongly support the government to "should restrict travel to the areas of the disease to avoid the spread of disease," "should provide specific hospitals for treating the patients during isolation period," "should isolate the patients who had visited areas where COVID-19 confirmed," which counted for $99.1 \%, 98.9 \%$, and $97.4 \%$, respectively.

Table 3. The answer rates of questionnaires of attitudes towards COVID-19

\begin{tabular}{|c|c|c|c|c|c|c|}
\hline & Attitudes questions & $\begin{array}{c}\text { I agree } \\
\mathrm{n}(\%)\end{array}$ & $\begin{array}{c}\text { I disagree } \\
\mathrm{n}(\%)\end{array}$ & $\begin{array}{l}\text { I don't } \\
\text { know } \\
\text { n }(\%)\end{array}$ & $95 \% \mathrm{CI}$ & $\begin{array}{c}\mathrm{p}- \\
\text { value }\end{array}$ \\
\hline 1. & $\begin{array}{l}\text { Do you agree that COVID-19 will finally be successfully } \\
\text { controlled? }\end{array}$ & $\begin{array}{l}3259 \\
(94.1)\end{array}$ & $42(1.2)$ & $163(4.7)$ & $\begin{array}{l}38.35- \\
111.51\end{array}$ & 0.000 \\
\hline 2. & $\begin{array}{l}\text { Do you have confidence that the Indonesian Government can win } \\
\text { the battle against the COVID-19 virus? }\end{array}$ & $\begin{array}{l}2829 \\
(81.7)\end{array}$ & $145(4.2)$ & $\begin{array}{c}490 \\
(14.1)\end{array}$ & $\begin{array}{l}29.7- \\
46.89\end{array}$ & 0.000 \\
\hline 3. & Important to report a suspected case to health authoritiesisep? & $\begin{array}{l}3444 \\
(99.4)\end{array}$ & $9(0.3)$ & $11(0.3)$ & $\begin{array}{l}8.11- \\
151.32\end{array}$ & 0.000 \\
\hline 4. & Closure of schools and work places during corona epidemic. & $\begin{array}{l}3374 \\
(97.4)\end{array}$ & $50(1.4)$ & $40(1.2)$ & $\begin{array}{c}11.44- \\
34.11\end{array}$ & 0.000 \\
\hline 5. & Afraid to go to common places in order not to get infection. & $\begin{array}{l}3375 \\
(97.4)\end{array}$ & $62(1.8)$ & $27(0.8)$ & $\begin{array}{l}6.73- \\
17.19\end{array}$ & 0.000 \\
\hline 6. & Corona infection can be treated at home & $\begin{array}{c}1152 \\
(33.3)\end{array}$ & $\begin{array}{l}2138 \\
(61.7)\end{array}$ & $174(5.0)$ & $3.75-6.05$ & 0.000 \\
\hline 7. & Corona infection is preventable. & $\begin{array}{c}3336 \\
(96.3)\end{array}$ & $34(1.0)$ & $94(2.7)$ & $\begin{array}{l}36.53- \\
169.39\end{array}$ & 0.000 \\
\hline 8. & $\begin{array}{l}\text { The government should restrict travel to the areas of the disease to } \\
\text { avoid spread of disease. }\end{array}$ & $\begin{array}{l}3433 \\
(99.1)\end{array}$ & $16(0.5)$ & $15(0.4)$ & $\begin{array}{l}11.61- \\
125.79\end{array}$ & 0.000 \\
\hline 9. & $\begin{array}{l}\text { The government should provide special hospitals for treating } \\
\text { infected patient during isolation period. }\end{array}$ & $\begin{array}{l}3427 \\
(98.9)\end{array}$ & $24(0.7)$ & $13(0.4)$ & $\begin{array}{l}5.76- \\
26.08\end{array}$ & 0.000 \\
\hline 10. & $\begin{array}{l}\text { The government should isolate infected patients who had visited } \\
\text { areas where COVID-19 confirmed. }\end{array}$ & $\begin{array}{l}3373 \\
(97.4)\end{array}$ & 54 (1.6) & $37(1.1)$ & $\begin{array}{l}11.61- \\
34.6\end{array}$ & 0.000 \\
\hline
\end{tabular}

The majority of the participants show the positive attitudes to battle and against the COVID-19 pandemic to prevent and mitigate it during the crisis period. The agreement rates of participants on 9 out 10 of attitudes questionnaires were ranging from $88.1-99.4 \%$. About $94.1 \%$ of participants believed that that COVID-19 would finally be successfully controlled, and $81.7 \%$ have confidence that the Indonesian government can win the battle against the COVID-19 virus; while $61.7 \%$ of participants disagree if someone who have corona infection can be treated at home. Important to report a suspected case to health authorities, and closure of schools and workplaces during the corona epidemic were strongly supported by participants, these about $99.4 \%$ and $97.4 \%$. Most of the participants are afraid to go to common places to avoid infection $(97.4 \%)$. The vast majority of participants are willing that the government should restrict travel to the areas of the disease to combat the spread of illness, provide specific hospitals for treating infected patients during isolation period, isolate infected patients. They had visited places where COVID-19 was confirmed. That counted for $99.1 \%, 98.9 \%$, and 97.4, respectively. Overall, women show a higher mean attitude score than 
the men (8.97, SD: 0.83). The lowest attitude score also comes from participants in Maluku/Papua/Papua Barat (8.86, SD: 0.92), graduated from elementary schools (8.5, SD: 0.70), unemployed (8.76, SD: 1.01), indigenous religions (7.50, SD: 3.69), and from divorced/widow status (8.56, SD: 1.30).

Participants who have living in marginalized areas such as rural or coastal tend to have no worried about COVID-19. The scholars identified that more contracting information related to COVID19 more the worried they have due to the overwhelming of information in TV [26]. Since the Muluku, Papua and Papua Barat situated in Eastern Indonesia we assumed that these regions as marginalised place and could affected people's attitude toward COVID19.

\subsection{Practices for prevention and mitigation of COVID-19}

The majority of participants show good practices to prevent and mitigate the COVID-19 pandemic as shown in Table 4. They always answer rates of the 10 questions on the COVID-19 prevention and mitigation practices questionnaire are 33.7-78.9\% as shown in Table 3. Nearly half of participants had not visited any crowded places (46\%), avoid visiting areas where someone confirmed a COVID-19 (77.3\%), wore masks when leaving home (49.1\%), and when feeling unwell (58.9\%) during a few days. The majority of participants had hand washing during a day (73.5\%) and using soap when hand washing (78.9\%). Among $1167(33.7 \%)$, participants had not shared domestic equipment such as towels and eating tools with family members. To promote a healthy lifestyle, more than a third of the participants doing physical activity every day, wearing a mask during work time, and had enough rest, and fruit and vegetables consumptions counted for around $37.2 \%, 38.6 \%$, and $47,5 \%$, respectively.

Table 4. COVID-19 prevention and mitigation practices

\begin{tabular}{|c|c|c|c|c|c|c|}
\hline & \multirow{2}{*}{ Self-reporting COVID-19 prevention and mitigation practices } & \multicolumn{5}{|c|}{ Answers (\%) } \\
\hline & & Always & Very often & Sometimes & Rarely & Never \\
\hline 1. & During this week, have gone to any crowded places & 3.2 & 4.9 & 15.7 & 30.2 & 46 \\
\hline 2. & During this week, had worn a mask when you were leaving home & 49.1 & 14.4 & 12.4 & 8.2 & 15.8 \\
\hline 3. & Hand washing during a day & 73.5 & 18.2 & 5.7 & 1.8 & 0.7 \\
\hline 4. & Using soap when hand washing & 78.9 & 14.3 & 5.1 & 1 & 0.8 \\
\hline 5. & $\begin{array}{l}\text { Don't share domestic equipment such as towel, eating tools with } \\
\text { family member }\end{array}$ & 33.7 & 12.6 & 17.3 & 8.9 & 27.5 \\
\hline 6. & Wearing a mask when you were feeling unwell & 58.9 & 15.6 & 13.7 & 5.1 & 6.8 \\
\hline 7. & Avoid to visit places where someone confirmed COVID-19 & 77.3 & 10 & 5.2 & 1.4 & 6.1 \\
\hline 8. & Doing regular physical activity in every day & 37.2 & 20.6 & 29.4 & 8.8 & 4 \\
\hline 9. & Wearing a mask during work time & 38.6 & 15 & 19.4 & 8.9 & 18.1 \\
\hline 10. & Have you enough rest, and fruits and vegetables consumption & 47.5 & 27 & 20.6 & 4.1 & 0.9 \\
\hline
\end{tabular}

Almost half of the participants reported that they have good practice in preventing and mitigation of COVID-19 in the community. The methods are supported by resident that do not go and visit any crowded places during a week (46\%), and avoid visiting places where someone confirmed of COVID-19 (77.3\%). Further, the residents wore a mask when leaving home during a week (49.1\%), washing hands during a day (73.5\%), and using soap when washing hands (78.9\%). Overall, women show better practices in the prevention and mitigation than men in which the mean practice score is 38.57 . This finding was similar with study result conducted by Chen et al where more than $90 \%$ of participants (China residents) concern on COVID-19 prevention by following the protocol such as low gathering, less going out, and wearing masks when leaving home [24]. Besides that, from gender-based participants women more actively engage in practice to prevent COVID-19 spreading than men, it was in line with study result investigated by Honarvar et al among Iranian in Shiraz province [27]. Another finding, that the Ecuadorians have similar characteristics with Indonesian residents were men, unemployed, and single persons have riskiest behaviour [28]. The some potential reasons why they have riskiest behaviour, as a single person all activities related food serving should provide alone, or as unemployed person brings the situation be unaffordable to purchase personnel protective equipment's such facemask. It's important to notice the study finding by Sahar and collegues that men, even as healthcare workers, had worse health practices in COVID-19 prevention efforts compared to women healthcare workers [29].

\subsection{Comparison socio-demographic characteristics and KAP variables of COVID-19}

In this study, analyzed that all socio-demographic characteristics namely gender, region of current place of residence, educational background, occupational types, religion affiliation, and marital status were having significantly correlate to knowledge about COVID-19 as shown in Table 5. Similarly, Bangladeshi scholars found that age, educational level and geographical distribution have significant relationship to 
knowledge [30]. A study in Beijing, China where the respondents were students in primary and secondary schools, the study result reported that students have good knowledge on COVID-19 [16]. Further, the researchers assumed that it could be affected by the student actively learn about COVID-19 from various information channels. In contrast, a study in Bangladesh where the researchers point out these respondents who have primary educational background has the lowest score on knowledge compared to all other educational group of respondents [30]. Previous study in China found that male reporting higher levels of knowledge than female [31] while a study in Bangladesh found that both males and females have similar level of knowledge on symptoms, precaution and prevention [30]. It was interesting to notice that, our study found that females have higher level of knowledge than males. However, this study finding could be affected by the imbalance of the research participant since the female took $70 \%$ of total participants

Table 5. The Socio-demographics and KAP variables

\begin{tabular}{|c|c|c|c|c|c|c|c|c|c|}
\hline \multirow{2}{*}{ Characteristics } & \multicolumn{2}{|c|}{ Knowledge } & \multirow{2}{*}{$\mathrm{p}$-value } & \multicolumn{2}{|c|}{ Attitudes } & \multirow{2}{*}{ p-value } & \multicolumn{2}{|c|}{ Practices } & \multirow{2}{*}{ p-value } \\
\hline & Poor & Good & & Poor & Good & & Poor & Good & \\
\hline \multicolumn{10}{|l|}{ Gender } \\
\hline Male & 410 & 626 & \multirow[t]{2}{*}{0,010} & 236 & 800 & \multirow[t]{2}{*}{0.038} & 544 & 492 & \multirow[t]{2}{*}{0.000} \\
\hline Female & 858 & 1570 & & 486 & 1982 & & 1081 & 1347 & \\
\hline \multicolumn{10}{|c|}{ Regions of current place residence } \\
\hline Sumatera & 47 & 135 & \multirow[t]{6}{*}{0.001} & 45 & 137 & \multirow[t]{6}{*}{0.084} & 84 & 98 & \multirow[t]{6}{*}{0.000} \\
\hline Jawa & 575 & 1015 & & 329 & 1261 & & 749 & 841 & \\
\hline Bali and Nusa Tenggara & 193 & 332 & & 87 & 438 & & 205 & 320 & \\
\hline Kalimantan & 129 & 149 & & 58 & 220 & & 145 & 133 & \\
\hline Sulawesi & 287 & 506 & & 180 & 613 & & 379 & 414 & \\
\hline Maluku and Papua & 37 & 59 & & 23 & 73 & & 63 & 33 & \\
\hline \multicolumn{10}{|l|}{ Educational } \\
\hline Never study & 6 & 5 & \multirow[t]{8}{*}{0.004} & 4 & 7 & \multirow[t]{8}{*}{0.007} & 5 & 6 & \multirow[t]{8}{*}{0.000} \\
\hline Elementary & 0 & 2 & & 1 & 1 & & 1 & 1 & \\
\hline Junior High & 7 & 13 & & 1 & 19 & & 3 & 17 & \\
\hline Senior High & 251 & 359 & & 123 & 487 & & 370 & 240 & \\
\hline Diploma & 165 & 345 & & 92 & 418 & & 195 & 315 & \\
\hline Bachelor & 675 & 1114 & & 410 & 1379 & & 822 & 967 & \\
\hline Master & 153 & 320 & & 78 & 395 & & 200 & 273 & \\
\hline Doctoral & 33 & 38 & & 13 & 36 & & 25 & 23 & \\
\hline \multicolumn{10}{|l|}{ Occupational } \\
\hline Student & 531 & 808 & \multirow[t]{6}{*}{0.001} & 271 & 1068 & \multirow[t]{6}{*}{0.032} & 736 & 603 & \multirow[t]{6}{*}{0.000} \\
\hline Public servants/ army /police & 236 & 514 & & 136 & 614 & & 277 & 473 & \\
\hline Private company officer & 298 & 554 & & 180 & 672 & & 333 & 519 & \\
\hline Self-employed & 45 & 80 & & 29 & 96 & & 50 & 75 & \\
\hline Household & 55 & 107 & & 44 & 118 & & 83 & 79 & \\
\hline Unemployed & 103 & 133 & & 62 & 174 & & 146 & 90 & \\
\hline \multicolumn{10}{|l|}{ Religion Affiliation } \\
\hline Islam & 930 & 1659 & 0.006 & 545 & 2044 & 0.030 & 1225 & 1364 & 0.000 \\
\hline Catholic & 104 & 159 & & 68 & 195 & & 135 & 128 & \\
\hline Christianity & 167 & 211 & & 78 & 300 & & 199 & 179 & \\
\hline Hindu & 62 & 158 & & 28 & 192 & & 57 & 163 & \\
\hline Buddhism & 3 & 4 & & 2 & 5 & & 3 & 4 & \\
\hline Confucianism & 1 & 2 & & 0 & 3 & & 2 & 1 & \\
\hline Indigenous Religions & 1 & 3 & & 1 & 3 & & 4 & 0 & \\
\hline Marital status & & & & & & & & & \\
\hline Single/Never married & 834 & 1304 & 0.001 & 464 & 1674 & 0.085 & 1105 & 1033 & 0.000 \\
\hline Married & 420 & 869 & & 247 & 1042 & & 507 & 782 & \\
\hline Divorce/widow & 14 & 23 & & 11 & 26 & & 13 & 24 & \\
\hline
\end{tabular}

In terms of attitudes towards COVID-19, in this study finding that gender, educational background, occupational types, and religion affiliation characteristics shows significant correlation to attitudes. In line with study conducted in Dhaka slum area where positive attitude were positively associated with gender, age, occupation, marital status, and family income [32]. Further the researchers emphasized that male, lower age, being unmarried, and having higher income as significant sub-categories in positive attitude. It was supported by a correlation analysis using the Pearson Correlation test, which shows that there are positive correlations between knowledge and attitudes $(\mathrm{p}<0.01)$. The results also in line with the previous studies which conducted one month after the first COVID-19 case announced in Indonesia, that knowledge positively correlates to attitudes [22]. Moreover, an epidemiological study in Nigeria also found the same result that a good level of knowledge have positive impact on attitudes on mitigating in spread of COVID-19 [33].

In agreement with our study findings, this study investigation result shows that practices among Indonesian residents in order to prevent and mitigation the COVID-19 in the community was significant 
correlation to all socio-demographic characteristics namely gender, region of current place of residence, educational background, occupational types, religion affiliation, and marital status. Since this study does not analysis the correlation between age of participants and KAP variables due the age of participants unclassified into age of group, the evidence between them we could not reported. However, the evidence from some previous studies showed that age was significantly associated with COVID-19 related practices [34]. Additionally, more frequent practices were significantly associated with knowledge about COVID-19 [32]. It was similar finding with our study, based on correlation analysis using the Pearson Correlation test shows that there are positive correlations between knowledge and practices $(p<0.01)$, and attitudes and practices $(\mathrm{p}<0.01)$. Knowledge also greatly reflects the individual as it provides a base acceptable practice [8]. A review study on practice during the COVID-19 pandemic identified that both healthcare and nonhealthcare workers in China have a good practice, in which healthcare workers focus on infection prevention practices while the non-healthcare workers and residents tend to avoid the crowded places, and wore the masks when leaving home [35]. Unneglected, increasing residents' include healthcare workers' knowledge through government and commercial information channel was adjusted behaviour and practices regarding COVID-19 prevention [31]. This study has identified factors associated with KAP. The findings are useful for policymakers to quickly consider the need for a comprehensive specific group of health education program related target for COVID-19 prevention and control [36].

The limitation of this study is that the participants were classified into region-based residency, which raises an issue whether the participants come across urban, semi-urban, and rural areas. Since the limited access of the Internet in rural areas, the residents' knowledge, attitudes, and practice may not be evaluated in this study. Besides, the recruitment of research participants through online form limits residents with no mobile phone, tablet, and computer to participate in this study [37]. It is a challenging issue to identify. Nevertheless, this is the first study recruiting significant number of participants throughout Indonesia residents.

\section{CONCLUSION}

In summary, we found that most Indonesian residents have good knowledge, positive attitudes, and good practice to promote COVID-19 prevention and mitigation to reduce the pandemic spreading within the country. Despite these findings, we found a lack of knowledge, attitudes, and practice among a particular group of participants such as men, residents in Kalimantan and Papua, have less formal education, unemployed, and are single/never married. To improve the knowledge, attitudes, and practices among them, the Indonesian government should put these critical aspects into account to provide a health education program

\section{REFERENCES}

[1] P. Kakodkar, N. Kaka, and M. Baig, "A Comprehensive Literature Review on the Clinical Presentation, and Management of the Pandemic Coronavirus Disease 2019 (COVID-19)," Cureus, vol. 12, no. 4, pp. 1-19, 2020.

[2] A. O. Docea et al., "A new threat from an old enemy: Re-emergence of coronavirus (Review)," Int. J. Mol. Med., vol. 45, no. 6, pp. 1631-1643, 2020.

[3] World Health Organization, WHO Coronavirus Disease (COVID-19), WHO Health Emergency Dashboard, 2021. [Online]. Available: https://covid19.who.int/?adgroupsurvey=\%7Badgroupsurvey\%7D\&gclid=CjwKCAiAxeX_BRASEiwAc1Qdkf9ir H8CF99hSA0oF98_WYyj9FmvwThG8IKvhQP-yApxQ7jxjYS6OhoC7bwQAvD_BwE

[4] B. Zareie, A. Roshani, M. A. Mansournia, M. A. Rasouli, and G. Moradi, "A model for COVID-19 prediction in Iran based on China parameters," Arch. Iran. Med., vol. 23, no. 4, pp. 244-248, 2020.

[5] M. Al-Mohaissen, "Awareness among a Saudi Arabian university community of Middle East respiratory syndrome coronavirus following an outbreak," East Mediterr Heal. J., vol. 23, no. 5, pp. 351-360, 2017.

[6] R. Güner, İ. Hasanoğlu, and F. Aktaş, 'Covid-19: Prevention and control measures in community', Turkish J. Med. Sci., vol. 50, no. 1, pp. 571-577, 2020.

[7] S. P. COVID-19, Info Grafis Kejadian COVID19, 2020. [Online]. Available: https://covid19.go.id/berita/infografiscovid-19-5-juni-2020

[8] I. Hussain et al., "Knowledge, Attitude, and Practices Toward COVID-19 in Primary Healthcare Providers: A Cross-Sectional Study from Three Tertiary Care Hospitals of Peshawar, Pakistan," J. Community Health, vol. 45, no. 6, pp. 1-9, 2020.

[9] A. I. Almuttaqi, "The omnishambles of COVID-19 response in Indonesia," THC Insigjts, vol. 1, no. 13, pp. 1-7, 2020.

[10] Kementrian Kesehatan RI, Pedoman dan Pencegahan Coronavirus (COVID- 19), vol. 5. Jakarta: Kementerian Kesehatan RI, 2020.

[11] B. A. Kassie, A. Adane, Y. T. Tilahun, E. A. Kassahun, A. S. Ayele, and A. K. Belew, "Knowledge and attitude 
towards COVID-19 and associated factors among health care providers in Northwest Ethiopia," PLoS One, vol. 15, no. 8, pp. 1-12, 2020.

[12] W. Y. Abdel Wahed, E. M. Hefzy, M. I. Ahmed, and N. S. Hamed, "Assessment of Knowledge, Attitudes, and Perception of Health Care Workers Regarding COVID-19, A Cross-Sectional Study from Egypt," J. Community Health, vol. 45, no. 6, pp. 1242-1251, 2020.

[13] R. M. Zeenny, E. Ramia, Y. Akiki, S. Hallit, and P. Salameh, "Assessing knowledge, attitude, practice, and preparedness of hospital pharmacists in Lebanon towards COVID-19 pandemic: A cross-sectional study," $J$. Pharm. Policy Pract., vol. 13, no. 1, pp. 1-12, 2020.

[14] B. L. Zhong et al., "Knowledge, attitudes, and practices towards COVID-19 among chinese residents during the rapid rise period of the COVID-19 outbreak: A quick online cross-sectional survey," Int. J. Biol. Sci., vol. 16, no. 10, pp. 1745-1752, 2020.

[15] M. K. Al-Hanawi et al., "Knowledge, Attitude and Practice Toward COVID-19 Among the Public in the Kingdom of Saudi Arabia: A Cross-Sectional Study," Front. Public Heal., vol. 8, no. 5, pp. 1-10, 2020.

[16] F. Wen et al., "Knowledge, attitudes, practices of primary and middle school students at the outbreak of COVID-19 in Beijing: A cross-sectional online study," medRxiv, vol. 1, no. 1, pp. 1-33, 2020.

[17] N. A. Pascawati and T. B. T. Satoto, "Public knowledge, attitudes and practices towards COVID-19," International Journal of Public Health Science, vol. 9, no. 4, pp. 292-302, 2020.

[18] A. A. Azlan, M. R. Hamzah, T. J. Sern, S. H. Ayub, and E. Mohamad, "Public knowledge, attitudes and practices towards COVID-19: A cross-sectional study in Malaysia," PLoS One, vol. 15, no. 5, pp. 1-15, 2020.

[19] D. Serwaa, E. Lamptey, A. B. Appiah, E. K. Senkyire, and J. K. Ameyaw, "Knowledge, risk perception and preparedness towards coronavirus disease-2019 (Covid-19) outbreak among ghanaians: A quick online crosssectional survey," Pan Afr. Med. J., vol. 35, no. 2, pp. 1-7, 2020.

[20] M. Z. Ferdous, M. S. Islam, M. T. Sikder, A. S. M. Mosaddek, J. A. Zegarra-Valdivia, and D. Gozal, "Knowledge, attitude, and practice regarding COVID-19 outbreak in Bangladesh: An onlinebased cross-sectional study," PLoS One, vol. 15, no. 10, pp. 1-17, 2020.

[21] Y. Y. Chen Yan, Jin Yuelong, Zhu Lijun, Fang Zhengmei, Wu Nan, Du Mengxue, Jiang Minmin, Wang Jing, "The network investigation on knowledge, attitude and practice about COVID-19 of the residents in Anhui Province," Chin J Prev Med, vol. 54, no. 4, pp. 367-373, 2020.

[22] D. K. Sari, R. Amelia, R. Dharmajaya, L. M. Sari, and N. K. Fitri, "Positive Correlation Between General Public Knowledge and Attitudes Regarding COVID-19 Outbreak 1 Month After First Cases Reported in Indonesia," $J$. Community Health, vol. 46, no. 1, pp. 182-189, 2021.

[23] N. M. Nasir, B. Baequni, and M. I. Nurmansyah, "Misinformation Related To Covid-19 in Indonesia," J. Adm. Kesehat. Indones., vol. 8, no. 1, pp. 51-59, 2020.

[24] F. Y. Sitepu et al., "A survey of the knowledge of surveillance officers and outbreak investigation team toward covid-19 in north sumatera province, indonesia," Open Access Maced. J. Med. Sci., vol. 8, no. T1, pp. 55-60, 2020.

[25] B. Yanti et al., "Community Knowledge, Attitudes, and Behavior Towards Social Distancing Policy As Prevention Transmission of Covid-19 in Indonesia," J. Adm. Kesehat. Indones., vol. 8, no. 1, pp. 4-14, 2020.

[26] L. L. Lau et al., "Knowledge, attitudes and practices of COVID-19 among income-poor households in the Philippines: A cross-sectional study," J. Glob. Health, vol. 10, no. 1, pp. 1-11, 2020.

[27] B. Honarvar et al., "Knowledge, attitudes, risk perceptions, and practices of adults toward COVID-19: a population and field-based study from Iran," Int. J. Public Health, vol. 65, no. 6, pp. 731-739, 2020.

[28] B. R. Bates, A. L. Moncayo, J. A. Costales, C. A. Herrera-Cespedes, and M. J. Grijalva, "Knowledge, Attitudes, and Practices Towards COVID-19 Among Ecuadorians During the Outbreak: An Online Cross-Sectional Survey," J. Community Health, vol. 45, no. 6, pp. 1158-1167, 2020.

[29] J. Sahar, S. M. Kiik, W. Wiarsih, and U. Rachmawati, "Coronavirus disease-19: Public health nurses' knowledge, attitude, practices, and perceived barriers in Indonesia," Open Access Maced. J. Med. Sci., vol. 8, no. 1, pp. 422428,2020

[30] M. A. Hossain et al., "Knowledge Attitudes and fear of COVID-19 during the Rapid Rise Period in Bangladesh," PLoS One, vol. 15, no. 9, pp. 1-13, 2020.

[31] M. Zhang et al., "Knowledge, attitude, and practice regarding COVID-19 among healthcare workers in Henan, China," J. Hosp. Infect., vol. 105, no. 2, pp. 183-187, 2020.

[32] S. Islam et al., "Knowledge, attitudes and practices associated with the COVID-19 among slum dwellers resided in Dhaka City: a Bangladeshi interview-based survey," J. Public Health (Bangkok)., vol. 1, no. 1, pp. 1-13, 2020.

[33] R. C. Reuben, M. M. A. Danladi, D. A. Saleh, and P. E. Ejembi, "Knowledge, Attitudes and Practices Towards COVID-19: An Epidemiological Survey in North-Central Nigeria," J. Community Health, vol. 45, no. 7, pp. 1-14, 2020.

[34] C. K. Edet, A. I. Wegbom, and V. A. Kiri, "Knowledge, Attitude and Practice of Clients towards COVID-19 at Primary Healthcare Facilities in Rivers State, Nigeria," Int. J. Trop. Dis. Heal., vol. 6, no. 1, pp. 1-12, 2020.

[35] I. M. Puspitasari, L. Yusuf, R. K. Sinuraya, R. Abdulah, and H. Koyama, "Knowledge, attitude, and practice during the COVID-19 pandemic: A review," J. Multidiscip. Healthc., vol. 13, no. 7, pp. 727-733, 2020.

[36] S. Rugarabamu, M. Ibrahim, and A. Byanaku, "Knowledge, attitudes, and practices (KAP) towards COVID-19: A quick online cross-sectional survey among Tanzanian residents," medRxiv, vol. 5, no. 5, pp. 1-18, 2020.

[37] R. Ssebuufu et al., "Awareness, knowledge, attitude and practice towards measures for prevention of the spread of COVID-19 in the Ugandans: A nationwide online cross-sectional Survey," medRxiv, vol. 5, no. 9, pp. 1-28, 2020. 